\title{
INFLUENCE OF MALFUNCTIONS OF SELECTED BUS SUBSYSTEMS ON BUS TRANSPORTATION SAFETY
}

\section{WPLYW USZKODZEŃ WYBRANYCH PODSYSTEMÓW AUTOBUSÓW NA BEZPIECZEŃSTWO REALIZOWANYCH PRZEWOZÓW}

\author{
Piotr Bojar ${ }^{1)}$, Maciej Woropay ${ }^{2)}$, Klaudiusz Migawa ${ }^{3)}$ \\ ${ }^{1)}$ Państwowa Wyższa Szkoła Zawodowa w Pile, \\ ${ }^{2)}$ Instytut Techniczny Wojsk Lotniczych, \\ ${ }^{3)}$ Uniwersytet Technologiczno - Przyrodniczy w Bydgoszczy
}

\begin{abstract}
This article introduces division of transport systems into land transport systems (road and rail) as well as land and water transport systems (inland and sea), depending on the type of environment in which these systems carry out their tasks. Such systems comprise the class of social engineering systems of the Man - Technological Object Environment $(M-T O-E)$ type. Such systems are influenced by forcing factors, leading to changes in their condition. Such factors may be divided into operational, external and anthropotechnical and they cause the degradation of the system on various levels, including a decrease of the degree of its safety. The article attempts to evaluate the safety of the operation of transport systems on the basis of the evaluation of the safety of the transport process carried out over a defined time interval $\Delta t$. The evaluation of the safety of the implemented transport process was prepared on the basis of a set of calculated index values determined depending on the type of transport.
\end{abstract}

Keywords: safety, undesirable event, transport system

Streszczenie: $W$ pracy dokonano klasyfikacji systemów transportowych na systemy: transportu ladowego (drogowego $i$ kolejowego), transportu powietrznego i wodnego (śródlądowego i morskiego), w zależności od rodzaju otoczenia, w którym systemy te realizuja swoje zadania. Systemy te należa do klasy systemów socjotechnicznych typu Człowiek - Obiekt Techniczny - Otoczenie, $\langle C-O T-O\rangle$. Na systemy te oddzialywaja czynniki wymuszające powodujące zmiany ich stanów. Czynniki te można podzielić na: robocze, zewnętrzne $i$ antropotechniczne, które $w$ różnym stopniu oddziaływaja na system $i$ w różny sposób wpływaja na jego degradacje, powodujaca obniżenie poziomu bezpieczeństwa jego działania. W pracy podjęto próbe wplyw uszkodzeń wybranych podsystemów autobusów na bezpieczeństwo realizowanych przewozów

Slowa kluczowe: bezpieczeństwo, zdarzenie niepożądane, system transportowy 
Influence of malfunctions of selected bus subsystems on bus transportation safety

Wplyw uszkodzeń wybranych podsystemów autobusów na bezpieczeństwo...

\section{INFLUENCE OF MALFUNCTIONS OF SELECTED BUS SUBSYSTEMS ON BUS TRANSPORTATION SAFETY}

\section{Introduction}

Transport systems are defined as the entirety of means and operations connected with movement of people and cargo. Transport systems are socio-technological systems of the Man - Technological Object - Environment $\langle\mathrm{M}-\mathrm{TO}-\mathrm{E}\rangle$ type. Due to the man situated in the system as well as its environment, transport systems should be, above all, dependable and safe. Moreover, they should not pose a threat to co-existing systems as well as natural environment.

While analyzing the reasons for occurrence of threats (possibilities of incurring losses as a result of a single undesirable event) one should consider the influence of each of the elements of the system on the occurrence of threats within them.

The increase in threats causes a decrease in the level of safety which should be understood as the state of the system where no unacceptable threats occur making the completion of a task in the conditions of acceptable risk impossible. In this article it has been assumed that the risk is a conditional possibility of the occurrence of losses as a result of a single undesirable event.

The most common kind of mass transport is bus transport since it does not require special traction while the cost of the purchase of a new bus constitutes around $20 \%$ of the price of a new tram, therefore the economical factor plays a very important role for the transport company. Moreover, the popularity of buses over other means of mass transport is strengthened by the high capacity of buses, easy access to road infrastructure, possibility of changes in transport routes depending on the current needs of the city, etc.. Safe implementation of the transport process depends on three basic factors: anthropotechnical, external and operational.

The influence of anthropotechnical factors is connected mainly to improper behavior by people situated in the system and its environment $[4,5]$. Therefore, their recognition and competent analysis allows us to identify the critical points within the operation of the system [6]. The influence of external factors mainly includes the road surface conditions as well as its infrastructure and the impact of weather factors [2, 3]. Operational factors influencing the safety of the implemented transport process depend on the technological state of buses used in the analyzed system $[1,2,4]$.

The article is an attempt at an evaluation of the technical condition of drives of buses used in the analyzed transport system. 
The current number of buses used in the analyzed transport system is shown in Table 1.

Tab. 1 Current number of buses of the analyzed transport system

\begin{tabular}{|c|c|c|c|c|c|c|c|c|c|c|c|c|}
\hline & $\stackrel{m}{\circ}$ & $\stackrel{1}{\check{C}}$ & $\bar{\Xi}$ & $\stackrel{\circ}{\circ}$ & ஓे & 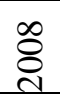 & స్요 & ஜ̊ & 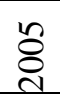 & ণิ & Б্ণ & 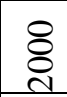 \\
\hline Solaris Urbino 8,6 & 2 & & & & & & & & & & & \\
\hline Solaris Urbino 18 & 11 & & & & & & & & & & & \\
\hline Solaris Urbino 12 & 14 & 2 & & & & & & & & & & \\
\hline $\begin{array}{l}\text { Mercedes Benz } \\
628 \text { Conecto G }\end{array}$ & & & 12 & 6 & 3 & & & & & & & \\
\hline $\begin{array}{l}\text { Mercedes Benz } \\
628 \text { Conecto LF }\end{array}$ & & & 4 & & 3 & 2 & & & & & & \\
\hline $\begin{array}{l}\text { Mercedes Benz } \\
628 \text { O } 530 \mathrm{G} \\
\text { Citaro }\end{array}$ & & & & & & 12 & 9 & & & & & \\
\hline $\begin{array}{l}\text { Mercedes Benz } \\
628 \text { O } 530 \text { Citaro }\end{array}$ & & & & & & & 2 & & & & & \\
\hline $\begin{array}{l}\text { Mercedes Benz } \\
671 \text { O } 345 \\
\text { Conecto }\end{array}$ & & & & & & & 9 & 13 & 10 & & & \\
\hline Volvo 7000A & & & & & & & & & & & 4 & \\
\hline Volvo B10 BLE & & & & & & & & & & & 6 & \\
\hline Volvo B10 L & & & & & & & & & & & & \\
\hline Volvo B10 MA & & & & & & & & & & & & \\
\hline MAN NG313 & & & & & & & & & & 2 & 2 & 5 \\
\hline MAN NL 223 & & & & & & & & & & & & 7 \\
\hline & 27 & 2 & 16 & 6 & 6 & 14 & 20 & 13 & 10 & 2 & 12 & 12 \\
\hline
\end{tabular}

As visible in the data included in Table 1 and Figure 1, 180 buses of various brands and types are used in the analyzed transport company. Out of these, around $32 \%$ are buses less than ten years old. Around $14 \%$ are twelve to fifteen year old buses, while $22 \%$ are buses used longer than 15 lat. Due to such diversity of fleet vehicles, the article is an attempt at the evaluation of technical condition of the powertrains of the buses used in the analyzed transport system. The object of research comprises powertrains of buses used in the system of municipal bus transport in a large urban agglomeration. The subject of research is the evaluation of the influence of the technical condition of the powertrain on the safety of the implemented transport process.

Fig. 2 represents a general diagram of the decomposition of the bus. A detailed decomposition of the powertrain subsystem was presented in Fig. 3. Table 2 contains the description of the decomposed subsystems of the powertrain system. As a result of the decomposition carried out in the powertrain subsystem, two subsystems were delineated: the engine with the accessories and the powertrain subsystem. 
Influence of malfunctions of selected bus subsystems on bus transportation safety Wplyw uszkodzeń wybranych podsystemów autobusów na bezpieczeństwo...

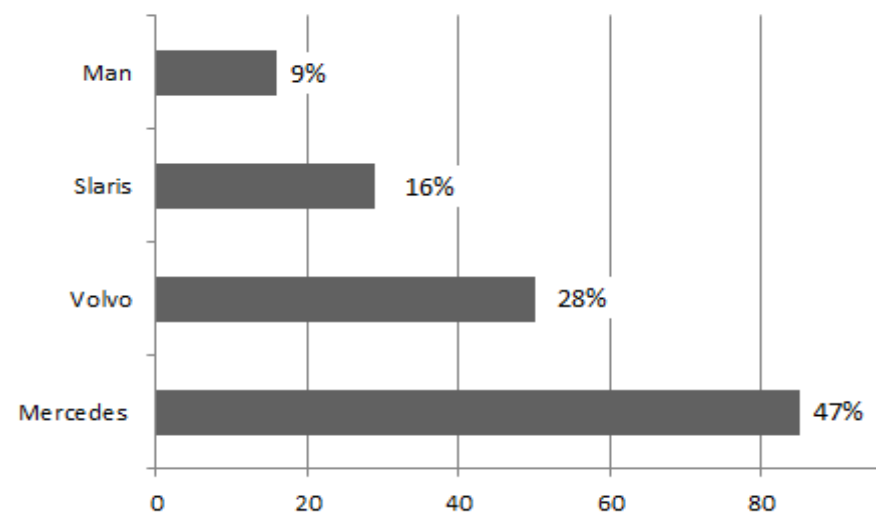

Fig. 1 Percentage of individual bus brands among the used fleet vehicles

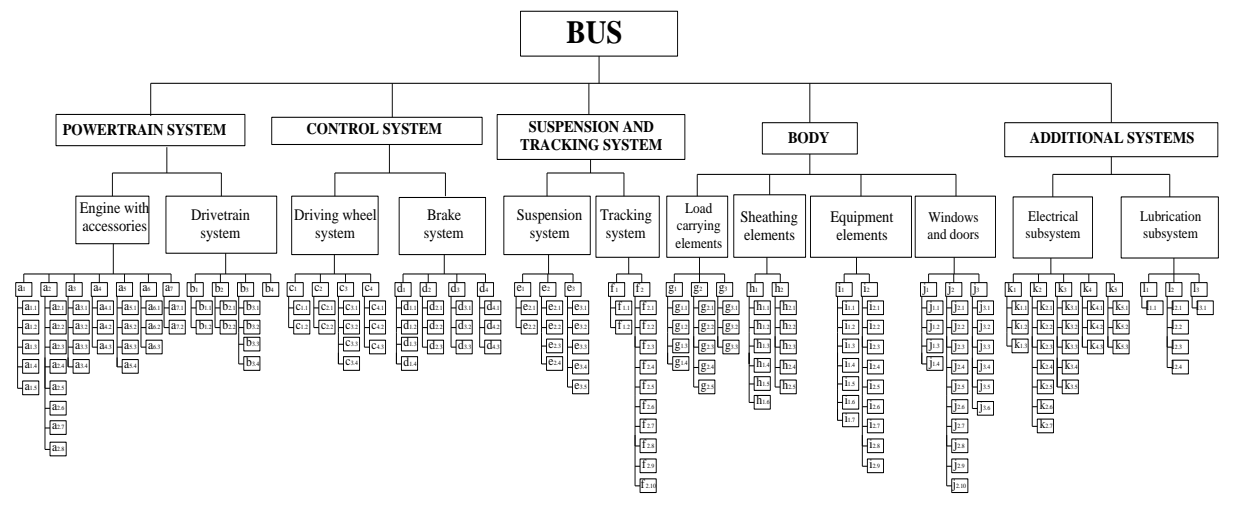

Fig. 2 Decomposition of the bus

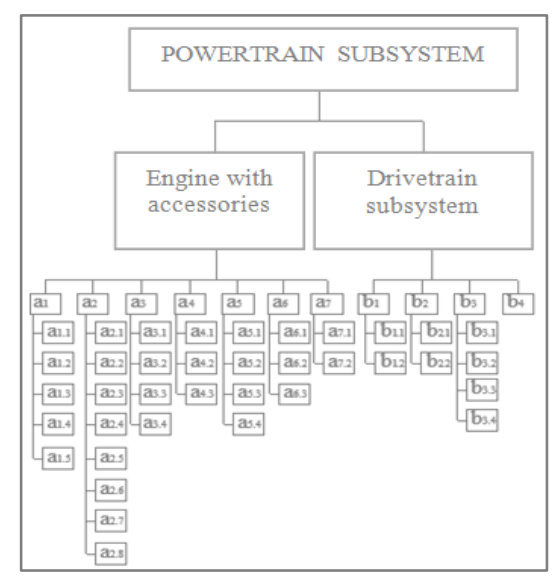

Fig.3. Decomposition of the powertrain system of the bus 
Table 2 Description of the decomposed subsystems presented in Fig. 3

\begin{tabular}{|c|c|c|}
\hline \multicolumn{3}{|c|}{ POWERTRAIN SUBSYSTEM } \\
\hline \multicolumn{3}{|c|}{ Engine with accessories } \\
\hline a 1 & \multicolumn{2}{|c|}{ Lubrication system } \\
\hline & $\overline{\text { a } 1.1}$ & Oil pump \\
\hline & a 1.2 & Oil cooler \\
\hline & a 1.3 & Oil pan \\
\hline & a 1.4 & Control equipment \\
\hline & a 1.5 & Filter subsystem \\
\hline a 2 & \multicolumn{2}{|c|}{ FUEL SUPPLY SYSTEM } \\
\hline & a 2.1 & Fuel pump \\
\hline & a 2.2 & Injection pump \\
\hline & a 2.3 & Injectors \\
\hline & a 2.4 & Fuel tank \\
\hline & a 2.5 & Filter subsystem \\
\hline & a 2.6 & Lines \\
\hline & a 2.7 & Air supply subsystem \\
\hline & a 2.8 & Injection control system \\
\hline a 3 & \multicolumn{2}{|c|}{ COOLING SYSTEM } \\
\hline & a 3.1 & Water pump \\
\hline & a 3.2 & Coolant tank \\
\hline & a 3.3 & $\begin{array}{ll}\begin{array}{l}\text { Radiator } \\
\text { subsystem }\end{array} & \text { ventilation } \\
\end{array}$ \\
\hline & a 3.4 & $\begin{array}{l}\text { Steering and control } \\
\text { devices }\end{array}$ \\
\hline \multirow[t]{4}{*}{ a 4} & \multicolumn{2}{|c|}{ Piston and crank system } \\
\hline & a 4.1 & Piston (set) \\
\hline & a 4.2 & Connecting rod (set) \\
\hline & a 4.3 & Crankshaft with flywheel \\
\hline
\end{tabular}

\begin{tabular}{|c|c|c|}
\hline a 5 & \multicolumn{2}{|c|}{ Valve timing system } \\
\hline & a 5.1 & $\begin{array}{l}\text { Elements of camshaft drive } \\
\text { system }\end{array}$ \\
\hline & a 5.2 & Valve control elements \\
\hline & a 5.3 & Valves \\
\hline & a 5.4 & $\begin{array}{ll}\text { Camshaft } & \text { sprocket } \\
\text { mounting plates } & \end{array}$ \\
\hline a 6 & \multicolumn{2}{|c|}{ Exhaust system } \\
\hline & a 6.1 & Exhaust pipes \\
\hline & a 6.2 & Muffler \\
\hline & a 6.3 & Brackets, clamps, saddles \\
\hline a 7 & \multicolumn{2}{|c|}{$\begin{array}{l}\text { ENGINE } \\
\text { HEAD }\end{array}$} \\
\hline & a 7.1 & Engine body \\
\hline & a 7.2 & Cylinder head \\
\hline \multicolumn{3}{|c|}{ DRIVETRAIN SUBSYSTEM } \\
\hline b 1 & \multicolumn{2}{|c|}{ Clutch } \\
\hline & b 1.1 & $\begin{array}{l}\text { Clutch } \\
\text { mechanism }\end{array}$ \\
\hline & b 1.2 & $\begin{array}{ll}\text { Clutch } & \text { operation } \\
\text { mechanism } & \\
\end{array}$ \\
\hline b 2 & \multicolumn{2}{|c|}{ GEARBOX WITH ACCESSORIES } \\
\hline & b 2.1 & $\begin{array}{l}\text { Transmission control } \\
\text { mechanism }\end{array}$ \\
\hline & b 2.2 & Automatic transmission \\
\hline b 3 & \multicolumn{2}{|c|}{ DRIVE AXLE } \\
\hline & b 3.1 & Main gearbox \\
\hline & b 3.2 & Differential \\
\hline & b 3.3 & $\begin{array}{l}\text { Half shafts and hubs of } \\
\text { drive axle }\end{array}$ \\
\hline & b 3.4 & Drive axle casing \\
\hline b 4 & \multicolumn{2}{|c|}{ TRANSMISSION SHAFT } \\
\hline
\end{tabular}

\section{Operational tests}

Operational tests were carried out in an existing transport system of a large urban agglomeration. The system uses 180 buses of different brands and types, as presented in Table 1. The tests were carried out as a passive experiment in which source data were analyzed relating to malfunctions of selected subsystems in the time period from January $1^{\text {st }}, 2013$ to December $31^{\text {st }}, 2013$. The obtained data related to the number of malfunctions of selected subsystems depending on the brand of the bus. Selected results of tests are presented in figures $4-7$. 
Influence of malfunctions of selected bus subsystems on bus transportation safety Wpływ uszkodzeń wybranych podsystemów autobusów na bezpieczeństwo...

\section{Selected test results and conclusions}

Figure 4 shows malfunctions of the engine and drivetrain in Solaris brand buses. According to the data included in the figure, most malfunctions relate to the drivetrain system, with the number of malfunctions of the subsystem amounting to $69 \%$ of all powertrain malfunctions. This is also valid for the remaining groups of tested buses where a decisive majority of malfunctions relates to the drivetrain subsystem. According to the data shown in Figure 4, the smallest number of malfunctions of both the engine and the drivetrain occurred in the months of May through July, with the total number of malfunctions in these months amounting to roughly $10 \%$ of all malfunctions. As visible in the presented test results, Solaris brand buses underwent a smaller number of malfunctions; this results from the fact that they are the newest vehicles in the fleet. Figure 5 presents malfunctions of Mercedes brand buses. The buses of this brand constitute the largest group of buses in service in the analyzed transport system, roughly $50 \%$ of the fleet vehicles. The largest number of malfunctions of the drivetrain subsystem in the analyzed group of buses occurred in the months of June through September. In this period of time the drivetrain in these buses malfunctioned 1,513 times, which constitutes $43 \%$ of the total number of malfunctions of this subsystem.

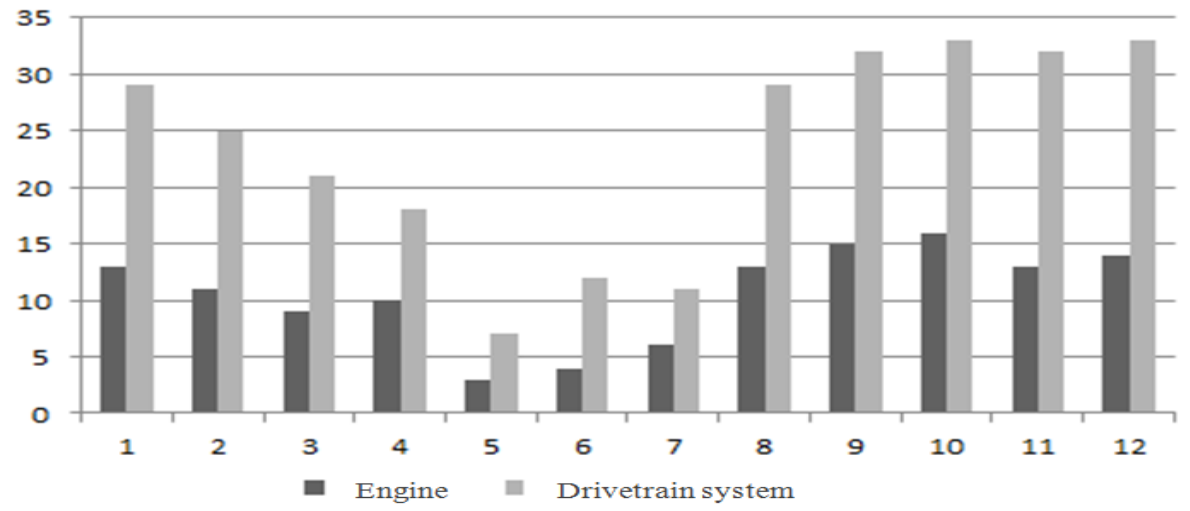

Fig. 4. Number of malfunctions of Solaris brand buses

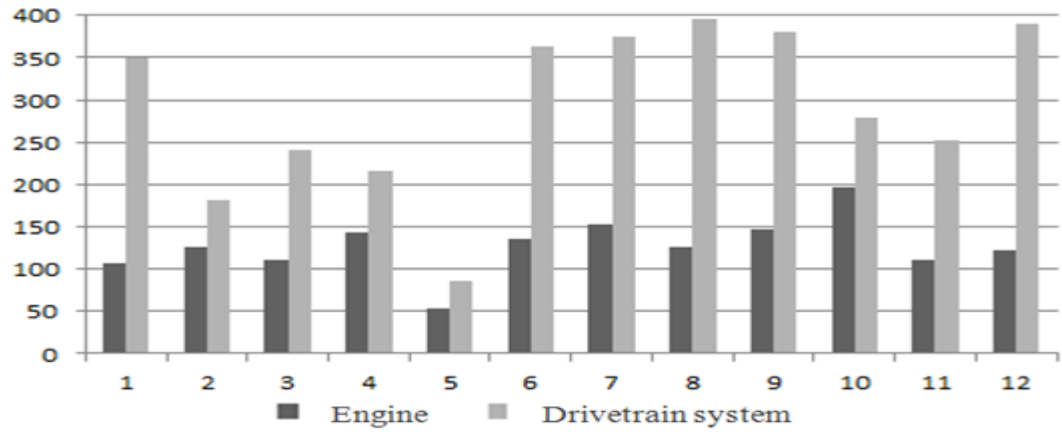

Fig. 5. Number of malfunctions of Mercedes brand buses 
Figure 6 shows the number of malfunctions over the analyzed time period in the group of Volvo brand buses. Buses of this manufacturer constitute $28 \%$ of company's fleet vehicles. Additionally, they are the oldest vehicles in the fleet of the company, with the average age of a bus running at 15 years old. Despite that, the average number of malfunctions of the engines in this group amounts to 43 malfunctions per month, with the average number for the whole fleet amounting to 53 malfunctions per month. The analysis of the average number of malfunctions of a single bus amounts to 8.5 with the average for the whole system equaling 14.2.

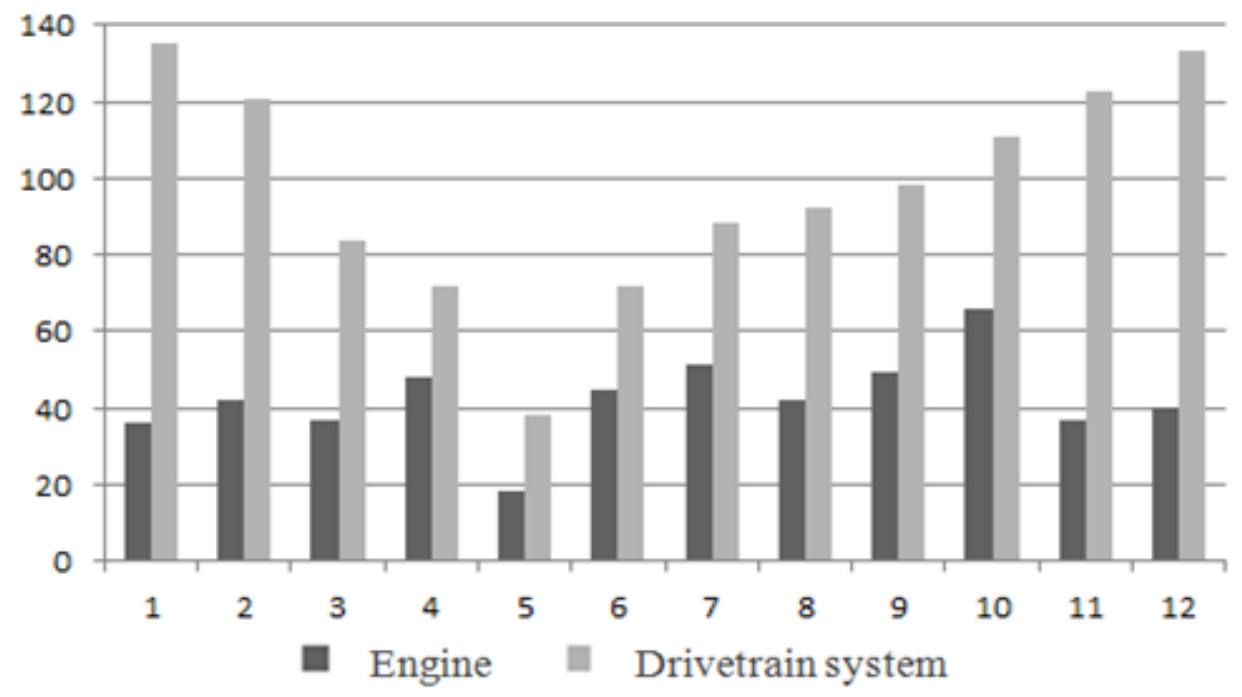

Fig. 6. Number of malfunctions of Volvo brand buses

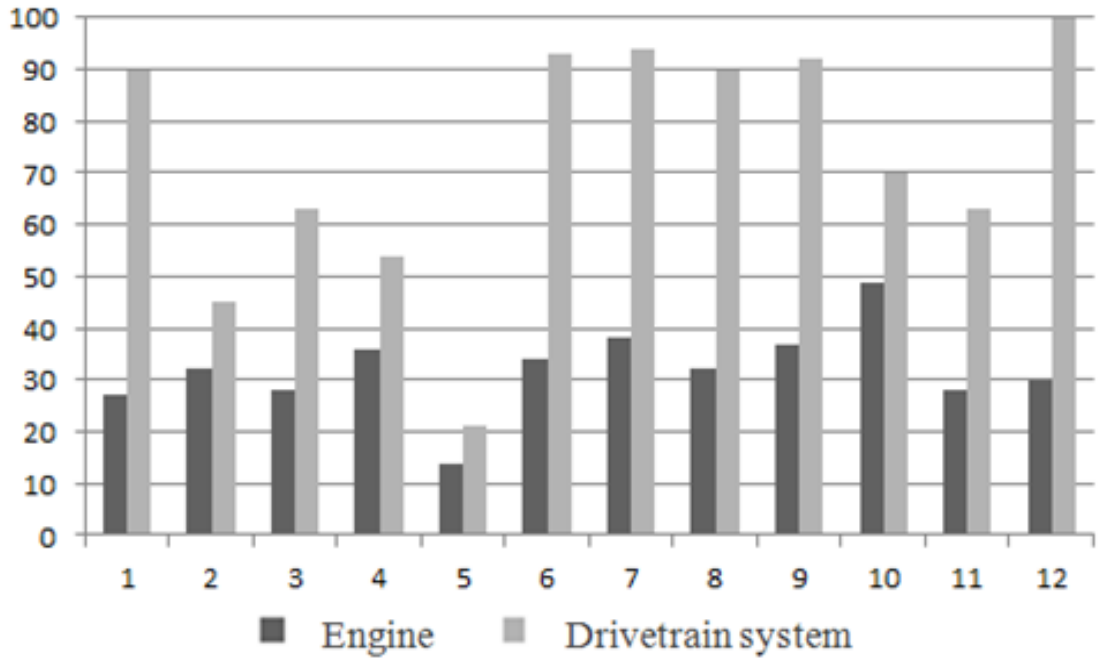

Fig. 7. Number of malfunctions of Man brand buses 
Influence of malfunctions of selected bus subsystems on bus transportation safety Wplyw uszkodzeń wybranych podsystemów autobusów na bezpieczeństwo...

Man brand buses constitute $20 \%$ of the means of transport in service in the analyzed research object. The number of malfunctions of the powertrain subsystem of this group of buses is presented in Figure 7. According to the data presented in this figure, the smallest number of engine malfunctions in these buses was recorded in the month of May; it amounted to 18 cases, less than $4 \%$ of the registered malfunctions. The largest number of malfunctions in this group of buses occurred in the month of October - 66 cases, amounting to $13 \%$ of recorded malfunctions.

\section{Summary}

The article has identified the means of transport in service in the bus transportation system of a large urban agglomeration in a system where operational tests were carried out in order to identify the number of malfunctions of the powertrain of the means of transport in service. The completed tests are part of introductory research aiming at identification of events in particular groups of buses. They serve as the basis for conducting a more detailed analysis in terms of identification of the malfunctioning elements of an analyzed subsystem, taking into consideration individual buses instead of the whole groups. As a result, an analysis of the condition of readiness of the buses in service will be possible. This, in turn, will serve as a basis for the development of a model of safety of transport system from the point of view of readiness of the means of transport used in the system.

\section{References}

[1]Piotr Bojar, Knopik Leszek: Analysis of external factors affecting transport process safety, Journal of KONES Powertrain and Transport, Vol. 20, No. 3 2013

[2]Piotr Bojar, Maciej Woropay, Mirosław Szubartowski: The method of evaluation of transport systems operation safety. Archives of transport, Warsaw 2013, pp. 43-55

[3] Piotr Bojar, Maciej Woropay: Road transport systems safety criteria, Journal of KONES Powertrain and Transport, Vol. 20, No. 42013

[4] Piotr Bojar: Proposed method for determining the value of safety features of the transport systems. Interdisciplinary integration of science in technology, education and economy, Khmelnytsky, Ukraine 2013

[5]Bojar P.: Wpływ wybranych czynników wymuszających na bezpieczeństwo przewozów realizowanych $\mathrm{W}$ systemie transportu zbiorowego. Logistyka w dobie zrównoważonego rozwoju [Influence of selected factors enforcing safety of transport carried out in mass transport system. Logistics in time of balanced development], Wydawnictwo BSW, Bydgoszcz 2012, pp. 138 - 156 
[6] Bartnicka J., Ziętkiewicz A., Kowalski G.: Ergonomicanalysis of surgeries with the use of wireless body postures measurement system. In: Innowacje $\mathrm{w}$ zarządzaniu i inżynierii produkcji [Innovations in manufacturing management and engineering]. Vol. 2. Ed. by Knosali R. Opole: Oficyna Wydaw. Polskiego Towarzystwa Zarządzania Produkcją, 2015, pp. 361-371

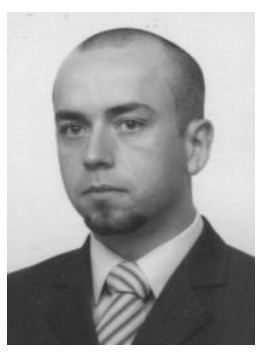

Piotr Bojar, D.Eng., is preoccupied in his academic research with the issues of reliability of complex technological systems as well as the evaluation of readiness of such systems, evaluation of safety of transport process implemented in existing transport systems and evaluation of the influence of forcing factors affecting such safety. Moreover, Dr. Bojar is interested in the problems of the quality of services in municipal mass transportation systems as well as evaluation of efficiency of such systems. His scientific interests also include logistics, especially urban logistics, hazardous material transport and ecologistics. He has been developing his academic interests in practice by evaluating the correctness of implemented transport tasks for businesses (Share 30\%).

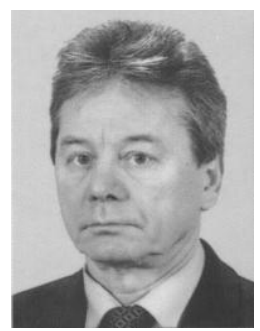

Maciej Woropay, Prof. D.Eng. Hab., is preoccupied in his academic research with such issues as safety of transport process, method of evaluation of transport in the context of the role of urbanization, its evolution and economical aspects. Moreover, his scientific research is centered around the evaluation of the level of readiness of means of transport used in existing municipal transport systems as well as development of models of utilization processes and evaluation of readiness and quality of services provided by transport companies. In addition, his research is related to the influence of diverse forcing factors on the safety and efficiency of mass public transport system (Share 40\%).

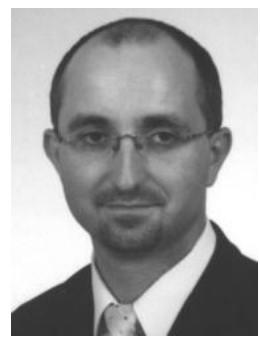

Assoc. Prof. Klaudiusz Migawa, Ph.D. D.Sc. Eng., works at the Faculty of Mechanical Engineering of the UTP University of Science and Technology in Bydgoszcz. In his scientific research he focuses on the problems of modeling and control of processes carried out in complex technological object operation systems. He conducts research on the evaluation of availability, reliability and safety in operation systems of municipal bus transport (Share 30\%). 


\section{WPLYW USZKODZEŃ WYBRANYCH PODSYSTEMÓW AUTOBUSÓW NA BEZPIECZEŃSTWO REALIZOWANYCH PRZEWOZÓW}

\section{Wstęp}

Systemy transportowe definiowane są jako ogół środków i działań związanych $\mathrm{z}$ przemieszczaniem osób i ładunków rzeczowych. Systemy transportowe są systemami socjotechnicznymi typu Człowiek - Obiekt Techniczny - Otoczenie <C - OT - O>. Ze względu na człowieka, umiejscowionego w systemie i jego otoczeniu, systemy transportowe powinny być przede wszystkim niezawodne i bezpieczne. Nie powinny również zagrażać systemom współistniejącym oraz środowisku naturalnemu.

Analizując przyczyny powstawania zagrożeń (możliwości powstania strat w wyniku wystąpienia pojedynczego zdarzenia niepożądanego), należy rozpatrzyć wpływ każdego z elementów systemu na powstawanie w nim zagrożeń.

Wzrost zagrożeń powoduje obniżenie poziomu bezpieczeństwa, które należy rozumieć jako stan systemu w którym nie występują niedopuszczalne zagrożenia co umożliwia realizację zadania $\mathrm{w}$ warunkach akceptowalnego ryzyka. W pracy przyjęto że ryzyko jest to warunkowa możliwość powstania strat w wyniku zajścia pojedynczego zdarzenia niepożądanego.

Najbardziej rozpowszechnionym rodzajem komunikacji zbiorowej jest komunikacja autobusowa, ponieważ nie wymaga ona specjalnych trakcji, koszt zakupu nowego autobusu stanowi około $20 \%$ ceny nowego tramwaju więc dla przedsiębiorstwa czynnik ekonomiczny odgrywa bardzo ważną rolę. Ponadto o popularności autobusów nad innymi środkami transportu zbiorowego świadczy fakt, dużej ładowności autobusów, łatwego dostępu do infrastruktury drogowej, możliwości zmian tras przewozowych $\mathrm{w}$ zależności od aktualnych potrzeb w mieście itp. Bezpieczna realizacji procesu transportowego uzależniona jest od trzech podstawowych czynników wymuszających: antropotechnicznych, zewnętrznych i roboczych.

Oddziaływania czynników antropotechnicznych dotyczą niewłaściwych zachowań ludzi usytuowanych w systemie i jego otoczeniu $[4,5]$. Oddziaływania czynników zewnętrznych to przede wszystkim stan nawierzchni drogi i jej infrastruktura oraz wpływ czynników atmosferycznych [2, 3]. Czynniki robocze oddziałujące na bezpieczeństwo realizowanego procesu transportowego zależą od stanu technicznego autobusów eksploatowanych w badanym systemie $[1,2,4]$.

W pracy podjęto próbę oceny stanu technicznego układów napędowych autobusów eksploatowanych w badanym systemie transportowym. Zestawienie aktualnego stanu autobusów badanego system transportowego przedstawiono w tabeli 1. 
Tab. 1 Zestawienie aktualnego stanu autobusów badanego system transportowego

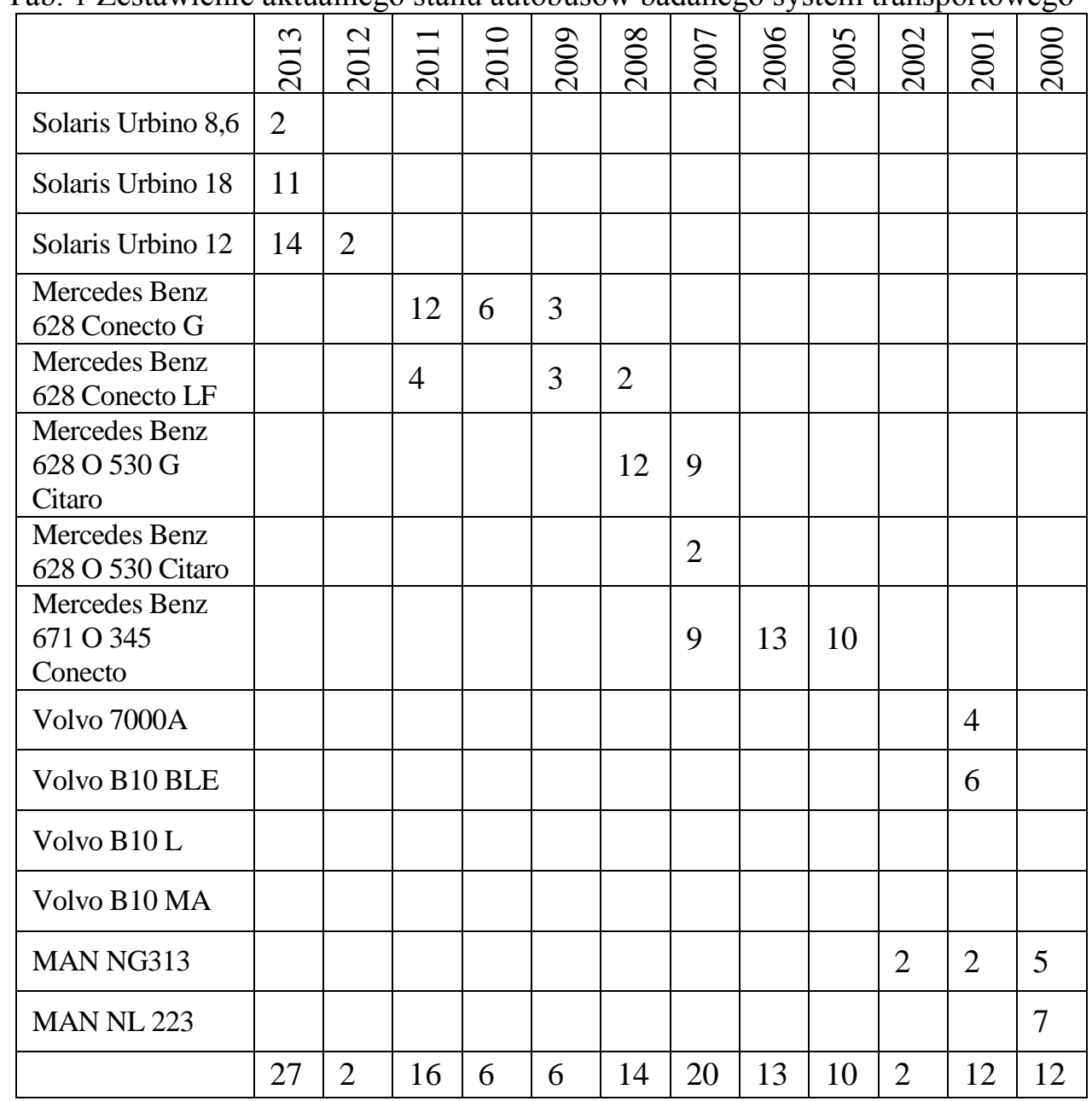

Jak wynika $\mathrm{z}$ danych zawartych $\mathrm{w}$ tabeli 1 i na rysunku $1 \mathrm{w}$ badanym przedsiębiorstwie transportowym eksploatowanych jest 180 autobusów różnych marek i typów. Z czego około $32 \%$ stanu są to autobusy w wieku do pięciu lat. Taki sam odsetek stanowią autobusy w wieku do dziesięciu lat. Około 14\% stanu stanowią autobusy 12-15letnie, a około 22\% autobusy eksploatowane dłużej niż 15 lat. Ze względu na tak zróżnicowany tabor w pracy podjęto próbę oceny stanu technicznego układu napędowego autobusów eksploatowanych w badanym systemie transportowym. Obiektem badań są układy napędowe autobusów eksploatowanych w systemie miejskiej komunikacji autobusowej w dużej aglomeracji miejskiej. Przedmiotem badań jest ocena stanu technicznego układu napędowego na bezpieczeństwo realizowanego procesu transportowego. 
Influence of malfunctions of selected bus subsystems on bus transportation safety Wplyw uszkodzeń wybranych podsystemów autobusów na bezpieczeństwo...

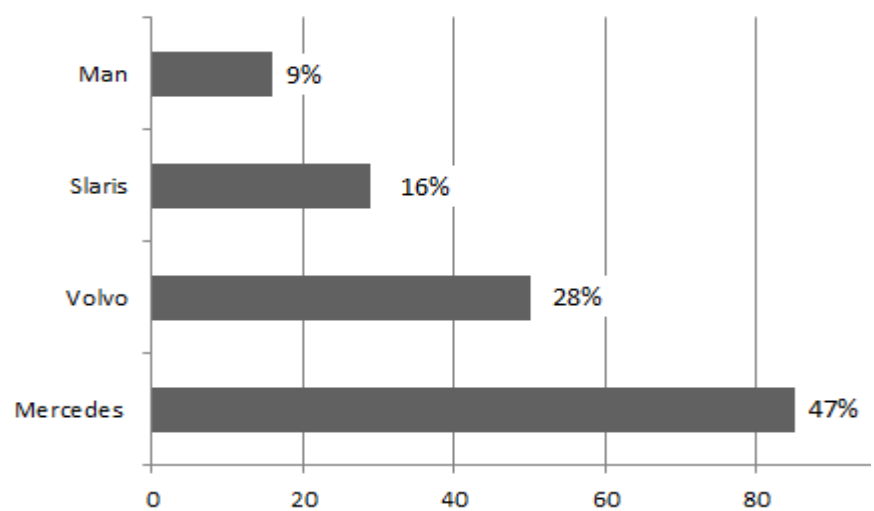

Rys. 1. Procentowy udział poszczególnej marki autobusów w eksploatowanym taborze

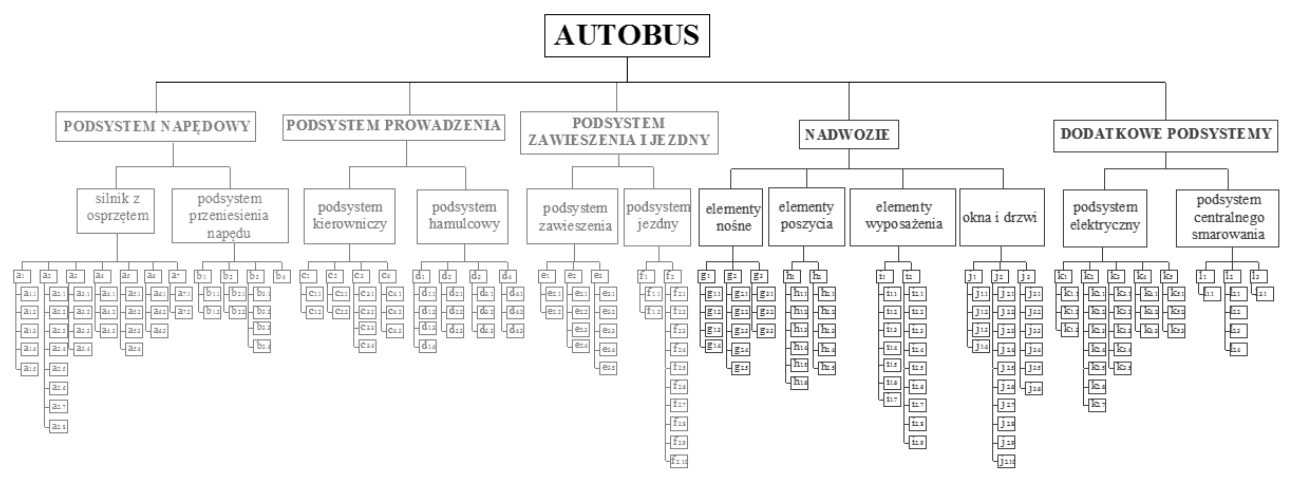

Rys. 2. Dekompozycja autobusu

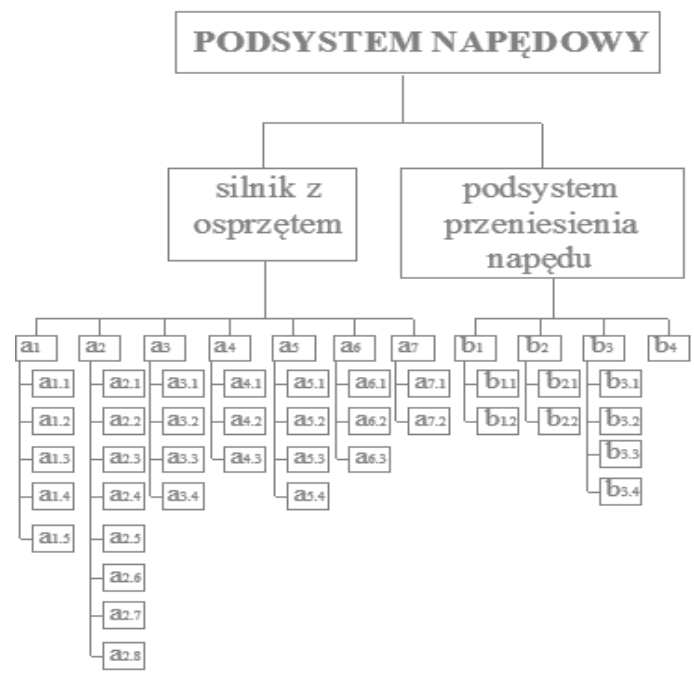

Rys.3. Dekompozycja uktadu napędowego autobusu 
Na rys 2 przedstawiono ogólny schemat dekompozycji autobusu. Szczegółową dekompozycję podsystemu napędowego przedstawiono na rys. 3. W tabeli 2 przedstawiono opis zdekomponowanych podsystemów układu napędowego. Jak wynika z przeprowadzonej dekompozycji w podsystemie napędowym wyróżniono dwa podsystemy: silnik z osprzętem i podsystem przeniesienia napędu.

Tabela 2 Opis zdekomponowanych podsystemów przedstawionych na rys. 3

\begin{tabular}{|c|c|c|c|c|c|}
\hline \multirow{2}{*}{\multicolumn{3}{|c|}{$\frac{\text { PODSYSTEM NAPĘDOWY }}{\text { Silnik z osprzętem }}$}} & $\underline{\mathrm{a} 5}$ & \multicolumn{2}{|c|}{ Układ rozrząa } \\
\hline & & & & a 5.1 & Elementy napędu rozrządu \\
\hline a 1 & \multicolumn{2}{|c|}{ Układ smarowania } & & a 5.2 & Elementy sterujące zaworami \\
\hline & a 1.1 & Pompa oleju & & a 5.3 & Zawory \\
\hline & a 1.2 & Chłodnica oleju & & a 5.4 & Obudowa kół napędu rorządu \\
\hline & a 1.3 & Zbiornik oleju & a 6 & \multicolumn{2}{|c|}{ Układ wydechowy } \\
\hline & a 1.4 & Urządzenia kontrolne & & a 6.1 & Przewody wydechowe \\
\hline & a 1.5 & Podsystem filtrujący & & a 6.2 & Thumiki \\
\hline \multirow[t]{9}{*}{ a 2} & \multicolumn{2}{|c|}{ UKŁAD ZASILANIA } & & a 6.3 & Wsporniki, zaciski, obejmy \\
\hline & a 2.1 & Pompa zasilająca paliwa & a 7 & \multicolumn{2}{|c|}{ KORPUS I GŁOWICE } \\
\hline & a 2.2 & Pompa wtryskowa & & a 7.1 & Korpus silnika \\
\hline & a 2.3 & Wtryskiwacze & & a 7.2 & Głowice silnika \\
\hline & a 2.4 & Zbirnik paliwa & \multicolumn{3}{|c|}{ Podsystem przeniesienia napędu } \\
\hline & a 2.5 & Podsystemk filtrujący & b 1 & \multicolumn{2}{|c|}{ Sprzeggło } \\
\hline & a 2.6 & Przewody & & b 1.1 & $\begin{array}{l}\text { Mechanizm sterujący } \\
\text { sprzęgła }\end{array}$ \\
\hline & a 2.7 & $\begin{array}{l}\text { Podsystem doladowania } \\
\text { powietrzem }\end{array}$ & & b 1.2 & $\begin{array}{l}\text { Mechanizm wykonwczy } \\
\text { sprzęgła }\end{array}$ \\
\hline & \multicolumn{2}{|c|}{\begin{tabular}{l|l} 
a 2.8 & wtryskiem \\
UKŁAD CHŁODZENIA
\end{tabular}} & b 2 & \multicolumn{2}{|c|}{$\begin{array}{l}\text { SKRZYNIA BIEGÓW Z } \\
\text { OSPRZETEM }\end{array}$} \\
\hline \multirow[t]{5}{*}{ a 3} & \multicolumn{2}{|c|}{ UKŁAD CHŁODZENIA } & & \multirow{2}{*}{ b 2.1} & \multirow{2}{*}{$\begin{array}{l}\text { Mechnizm sterujący } \\
\text { skrzyni biegów }\end{array}$} \\
\hline & a 3.1 & Pompa płynu chłodzącego & & & \\
\hline & a 3.2 & Zbiorniki płynu chłodzącego & & b 2.2 & $\begin{array}{l}\text { Automatyczna skrzynia } \\
\text { biegów }\end{array}$ \\
\hline & a 3.3 & $\begin{array}{l}\text { Podsystem wentylacji } \\
\text { chłodnicy }\end{array}$ & b 3 & \multicolumn{2}{|c|}{ MOST NAPĘDOWY } \\
\hline & a 3.4 & $\begin{array}{l}\text { Urządzenia sterujące i } \\
\text { kontrolne }\end{array}$ & & b 3.1 & Przekładnia główna \\
\hline \multirow[t]{4}{*}{ a 4} & \multicolumn{2}{|c|}{ Układ tłokowo-korbowy } & & b 3.2 & Mechanizm różnicowy \\
\hline & a 4.1 & Tłok (komplet) & & \multirow{2}{*}{ b 3.3} & \multirow{2}{*}{$\begin{array}{l}\text { Półosie i piasty mostu } \\
\text { napędowego }\end{array}$} \\
\hline & a 4.2 & Korbowód (komplet) & & & \\
\hline & a 4.3 & $\begin{array}{l}\text { Wał korbowy z kołem } \\
\text { zamachowym }\end{array}$ & & b 3.4 & $\begin{array}{l}\text { Obudowa mostu } \\
\text { napędowego }\end{array}$ \\
\hline & & & b 4 & TRAI & MISSION SHAFT \\
\hline
\end{tabular}


Influence of malfunctions of selected bus subsystems on bus transportation safety Wplyw uszkodzeń wybranych podsystemów autobusów na bezpieczeństwo...

\section{Badania eksploatacyjne}

Badania eksploatacyjne zrealizowano w rzeczywistym systemie transportowym w dużej aglomeracji miejskiej. W systemie tym eksploatowanych jest 180 autobusów różnych marek i typów, co przedstawiono w tabeli 1. Badania zrealizowano jako eksperyment bierny w którym przeanalizowano dane źródłowe dotyczące uszkodzeń wybranych podsystemów w przedziale czasu od 1.01. 2013 do 31.12.2013. Pozyskane dane dotyczyły liczby uszkodzeń wybranych podsystemów, w zależności od marki autobusu. Wybrane wyniki badań przedstawiono na rysunkach $4-7$.

\section{Wybrane wyniki badań i wnioski}

$\mathrm{Na}$ rysunku 4 przedstawiono uszkodzenia silnika i układu przeniesienia napędu $\mathrm{w}$ autobusach marki Solaris. Jak wynika $\mathrm{z}$ danych zawartych na rysunku zdecydowana większość uszkodzeń dotyczy układu przeniesienia napędu, liczba uszkodzeń tego podsystemu stanowi około 69\% wszystkich uszkodzeń układu napędowego. Taki stan rzeczy jest również w pozostałych grupach badanych autobusów, zdecydowana większość uszkodzeń układu napędowego dotyczy podsystemu przeniesienia napędu. Jak wynika $\mathrm{z}$ danych przedstawionych na rysunku 4 do najmniejszej liczby uszkodzeń zarówno silnika jak i układu przeniesienia napędu doszło $\mathrm{w}$ miesiącach od maja do lipca łączna liczba uszkodzeń $\mathrm{w}$ tych miesiącach stanowi około $10 \%$ wszystkich zaistniałych uszkodzeń. Jak widać z prezentowanych wyników badań autobusy marki Solaris ulegały zdecydowanie mniejszej liczbie uszkodzeń wynika to $\mathrm{z}$ tego że jest to najnowszy tabor. Na rysunku 5 przedstawiono uszkodzenia autobusów marki Mercedes. Autobusy tej marki stanowią największą grupę eksploatowanych pojazdów w badanym systemie transportowym, stanowią około $50 \%$ eksploatowanego taboru. Do największej liczby uszkodzeń podsystemu przeniesienia napędu $\mathrm{w}$ badanej grupie autobusów doszło w miesiącach od czerwca do września. W tym przedziale czasu układ przeniesienia napędu $\mathrm{w}$ tych autobusach uszkodził się 1513 razy co stanowi 43\% ogółu uszkodzeń tego podsystemu.

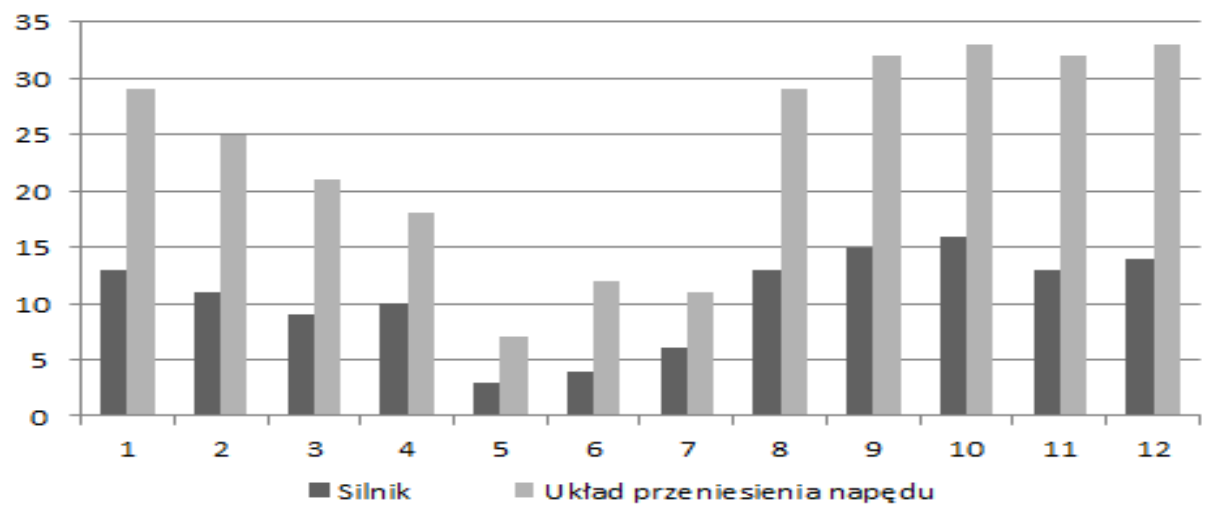

Rys. 4. Liczba uszkodzeń autobusów marki Solaris 


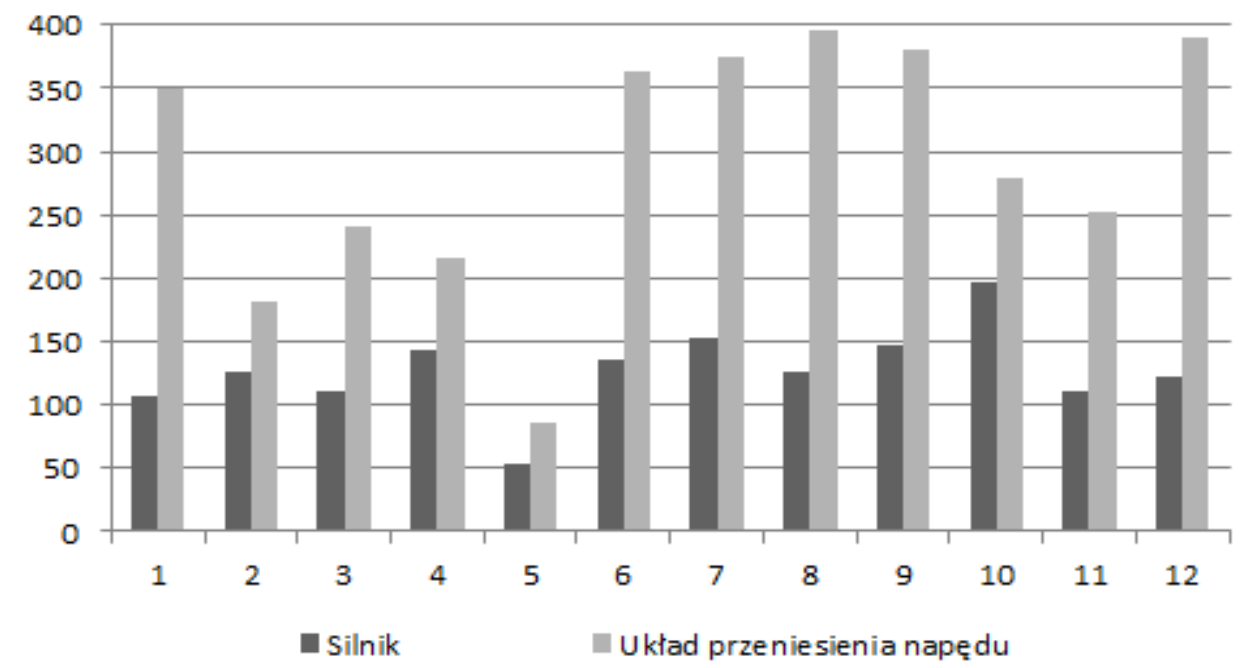

Rys. 5. Liczba uszkodzeń autobusów marki Mercedes

Na rysunku 6 przedstawiono liczby uszkodzeń w analizowanym czasie w grupie autobusów marki Volvo. Autobusy tego producenta stanowią 28\% eksploatowanego $\mathrm{w}$ przedsiębiorstwie taboru. Zarazem jest to najstarszy eksploatowany tabor w przedsiębiorstwie średnia wieku autobusu $\mathrm{z}$ tej grupy to 15 lat. Pomimo tego średnia liczba uszkodzeń silników w tej grupie autobusów wynosi 43 uszkodzenia na miesiąc, przy średniej dla całego taboru równej 53 uszkodzenia na miesiąc. Analizując średnią liczba uszkodzeń silnika jednego autobusu wynosi ona 8.5 przy średnie dla całego systemu równej 14,2.

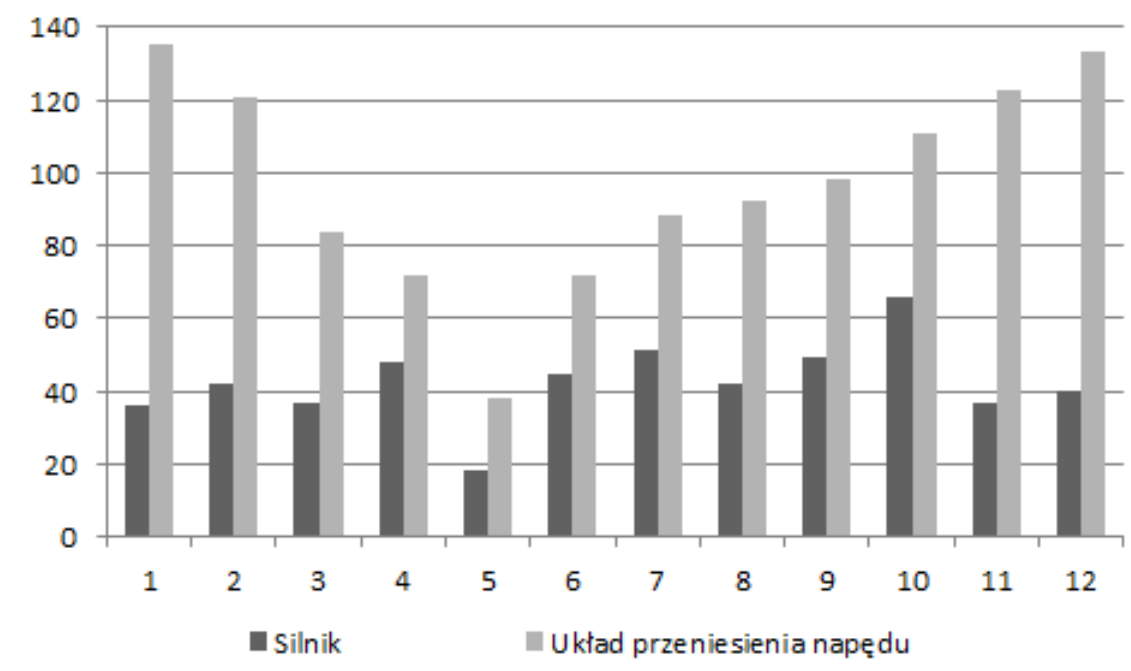

Rys. 6. Liczba uszkodzeń autobusów marki Volvo 
Influence of malfunctions of selected bus subsystems on bus transportation safety Wpływ uszkodzeń wybranych podsystemów autobusów na bezpieczeństwo...

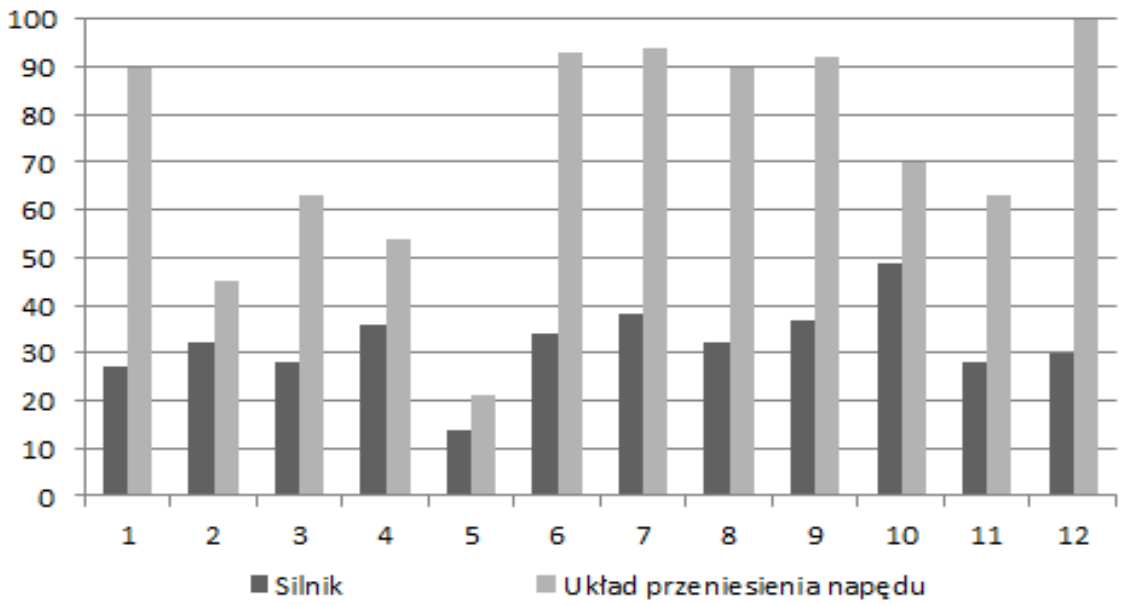

Rys. 7. Liczba uszkodzeń autobusów marki Man

Autobusy marki Man stanowią 20\% środków transportu eksploatowanych w analizowanym obiekcie badań. Liczbę uszkodzeń podsystemu napędowego tej grupy autobusów przedstawiono na rysunku 7. Jak wynika $\mathrm{z}$ danych przedstawionych na tym rysunku najmniejszą liczbę uszkodzeń silników tych autobusów odnotowano w miesiącu maju wynosiła ona 18 zdarzeń co stanowi niespełna 4\% zarejestrowanych uszkodzeń. Do największej liczby uszkodzeń silnika w tej grupie autobusów doszło w miesiącu październiku 66 zdarzeń co daje $13 \%$ odnotowanych uszkodzeń.

\section{Podsumowanie}

W pracy dokonano identyfikacji środków transportu eksploatowanych w systemie komunikacji autobusowej dużej aglomeracji miejskiej, w systemie tym zrealizowano badania eksploatacyjne w zakresie identyfikacji liczby uszkodzeń podsystemu napędowego eksploatowanych środków transportu. Zrealizowane badania stanowią badania wstępne mające na celu identyfikację zdarzeń $\mathrm{w}$ poszczególnych grupach autobusów. Stanowią one podstawę do przeprowadzenia bardziej szczegółowej analizy w zakresie identyfikacji uszkadzanych elementów badanego podsystemu, z uwzględnieniem nie całych grup autobusów a poszczególnych autobusów. Pozwoli to na analizę stanu zdatności eksploatowanych autobusów. Tak szczegółowa analiza umożliwi ocenę wpływu długości tras przewozowych na niezawodność środków transportu oraz ocenę stanu zdatności na poszczególnych liniach. Badania te pozwolą na ocenę wpływu stanu zdatności autobusów na bezpieczeństwo realizowanego procesu transportowego oraz na terminowość realizowanych przewozów.

\section{Literatura}

[1]Piotr Bojar, Knopik Leszek: Analysis of external factors affecting transport process safety, Journal of KONES Powertrain and Transport, Vol. 20, No. 3 2013 
[2]Piotr Bojar, Maciej Woropay, Mirosław Szubartowski: The method of evaluation of transport systems operation safety. Archives of transport, Warsaw 2013, pp. 43-55

[3] Piotr Bojar, Maciej Woropay: Road transport systems safety criteria, Journal of KONES Powertrain and Transport, Vol. 20, No. 42013

[4]Piotr Bojar: Proposed method for determining the value of safety features of the transport systems. Interdisciplinary integration of science in technology, education and economy, Khmelnytsky, Ukraine 2013

[5]Bojar P.: Wpływ wybranych czynników wymuszających na bezpieczeństwo przewozów realizowanych $\mathrm{w}$ systemie transportu zbiorowego. Logistyka w dobie zrównoważonego rozwoju [Influence of selected factors enforcing safety of transport carried out in mass transport system. Logistics in time of balanced development], Wydawnictwo BSW, Bydgoszcz 2012, pp. 138 - 156

[6] Bartnicka J., Ziętkiewicz A., Kowalski G.: Ergonomicanalysis of surgeries with the use of wireless body postures measurement system. In: Innowacje $\mathrm{w}$ zarządzaniu i inżynierii produkcji [Innovations in manufacturing management and engineering]. Vol. 2. Ed. by Knosali R. Opole: Oficyna Wydaw. Polskiego Towarzystwa Zarządzania Produkcją, 2015, pp. 361-371

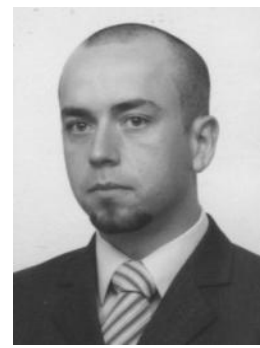

Dr inz. Piotr Bojar, w pracy naukowej zajmuje się analiza bezpieczeństwa stystemów trasportowych, a w szczególności systemów zbiorowego transport miejskiego. Ponadto zainteresowania naukowe dotycza oceny gotowości i jakości świadczonych ustug przewozowych $w$ systemach transportu miejskiego. Jest autorem $i$ wspótautorem prac z zakresu bezpieczeństwa, eksploatacji a także logistyki (Udziat 30\%).

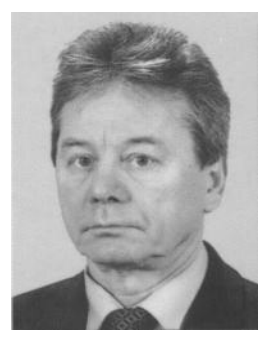

Prof. dr hab. inz. Maciej Woropay, w pracy naukowej zajmuje się problemami dotyczacymi teorii systemów, teorii niezawodności $i$ bezpieczeństwa oraz sterowania procesami eksploatacji $w$ złożonych systemach biotechnicznych, a w szczególności sterowaniem tymi procesami $w$ systemach transportu miejskiego. Jest autorem $i$ wspótautorem ponad 140 prac naukowych opublikowanych $w$ kraju $i$ za granica, a także podręczników $i$ skryptów akademickich, promotorem ponad 150 prac magisterskich i inżynierskich oraz prac doktorskich (Udziat 40\%).

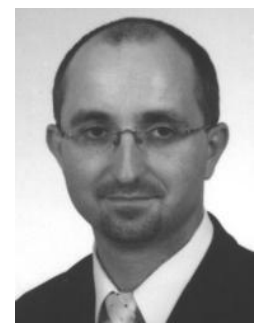

Dr hab. inz. Klaudiusz Migawa, pracuje na Wydziale InżynieriiMechanicznej Uniwersytetu Technologiczno Przyrodniczego w Bydgosczy. W pracy naukowej zajmuje sie modelowaniemi sterowaniem gotowościq techniczna systemów transportowych. Ponadto jest autorem $i$ wspótautorem prac z zakresu niezawodności, bezpieczeństwa oraz jakości systemów (Udziat 30\%). 
Influence of malfunctions of selected bus subsystems on bus transportation safety Wplyw uszkodzeń wybranych podsystemów autobusów na bezpieczeństwo... 